\title{
Mating system of monoecious Araucaria angustifolia (Bert.) O. Kuntze, a predominately dioecious conifer species
}

\author{
Moeses Andrigo Danner ${ }^{1 *}$, Juliana Zanetti Ribeiro², Flávio Zanette ${ }^{2}$, Juliana Vitória Messias Bittencourt ${ }^{3}$, \\ Alexandre Magno Sebbenn ${ }^{4}$
}

From 5th Congress of the Brazilian Biotechnology Society (SBBIOTEC)

Florianópolis, Brazil. 10-14 November 2013

\section{Background}

Araucaria angustifolia (Bert.) O. Kuntze is a mainly dioecious species that reproduces through outcrossing. However, some monoecious trees have been identified and they may reproduce through self-fertilization. The objective of this study was to confirm the expected relatedness of self-sibs of hand self-pollinated monoecious seed trees, and to investigate the mating system of open-pollinated progenies of monoecious A. angustifolia trees.

\section{Methods}

To obtain the A. angustifolia progenies, we collected seeds from open-pollinated trees from three monoecious trees (MN_Ara, MN_SD and MN_Gua) and selfing was induced by hand-pollinating the monoecious tree PF_3. The seedlings of each progeny were labeled and needles were collected from 18 offspring from each progenies. Samples were lyophilized and the isolation of DNA followed the protocol described in [1]. Eight microsatellite loci (CRCAc1, As90, Ag20, Ag23, Ag45, Aang01, Aang14 and Aang28) were used to genotype the samples. Polymorphism was detected by labeling primers and PCR multiplex with fluorescent dyes, followed by fragment detection by capillary electrophoresis in automated sequencer. The size of the fragments (alleles) was determined and was estimated the mating system parameters using the MLTR software [2].

\section{Results and conclusions}

Our results show that the selfed progenies (PF_3 $\times$ PF_3) are unquestionably the result of selfing $\left(t_{m}=0.00 \pm 0.00\right.$, $\left.r_{s}=0.99 \pm 0.01, P_{S S}=1, \Theta=0.5, N_{e}=1\right)$ and all offspring are self-sibs, confirming the efficacy of induced selfing through hand-pollination of a monoecious tree. The three open-pollinated progenies of monoecious trees showed high multi-locus outcrossing rate $\left(t_{m}\right)$ values, but the values were significantly lower than unity $(0.94 \pm 0.01$ and $0.95 \pm 0.01$ ), suggesting that some selfing did occur. The multilocus paternity correlation $\left(r_{p(m)}\right)$ of monoecious trees ranged from 0.10 to 0.29 and the progeny from MN_Ara produced values significantly higher than the two other progenies. The effective number of pollen donors $\left(N_{e p}\right)$ of these progenies ranged from 3.4 to 9.8 , the coancestry coefficient within progenies $(\Theta)$ ranged from 0.152 to 0.172 and variance effective size ranged from 2.63 to 2.92. The open-pollinated progenies of monoecious seed trees were mainly half-sibs $\left(P_{H S}\right.$ ranged from 0.63 to 0.79 ). Thus, the monoecious trees are reproductive mode by xenogamy, generating progeny with low proportion of self-sibs. The lower number of androstrobilus compared to ginostrobilus, as was observed in the monoecious tree PF_3, beyound heterozygous embryo selection in early stages, which occurs in A. angustifolia seeds [3], may explain the high outcrossing rate. Our results also suggest that monoecious trees have limited potential to modify the genetic structure through selfed seed production due to the very low estimated selfing rate and the rare occurrence of these trees in natural populations.

${ }^{1}$ Universidade Tecnológica Federal do Paraná, Dois Vizinhos, Brazil Full list of author information is available at the end of the article 


\section{Acknowledgements}

The authors would like to thank the Coordenação de Aperfeiçoamento de Pessoal de Nível Superior (CAPES) and the Fundação Araucária for providing support in this research.

\section{Authors' details}

'Universidade Tecnológica Federal do Paraná, Dois Vizinhos, Brazil.

${ }^{2}$ Universidade Federal do Paraná, Curitiba, Brazil. ${ }^{3}$ Universidade Tecnológica Federal do Paraná, Ponta Grossa, Brazil. Instituto Florestal de São Paulo, São Paulo, Brazil.

Published: 1 October 2014

\section{References}

1. Ferreira ME, Grattapaglia D: Introdução ao uso de marcadores moleculares em análise genética. Brasilia: Embrapa Cenargen 1996.

2. Ritland K: Extensions of models for the estimation of mating systems using $n$ independent loci. Heredity 2002, 88:221-228.

3. Agapito-Tenfen SZ, Steiner N, Guerra MP, Nodari RO: Patterns of polyembryony and frequency of surviving multiple embryos of the Brazilian pine Araucaria angustifolia. Australian Journal of Botany 2011, 59(8):749-755.

doi:10.1186/1753-6561-8-S4-P103

Cite this article as: Danner et al:: Mating system of monoecious Araucaria angustifolia (Bert.) O. Kuntze, a predominately dioecious conifer species. BMC Proceedings 2014 8(Suppl 4):P103.

\section{Submit your next manuscript to BioMed Central} and take full advantage of:

- Convenient online submission

- Thorough peer review

- No space constraints or color figure charges

- Immediate publication on acceptance

- Inclusion in PubMed, CAS, Scopus and Google Scholar

- Research which is freely available for redistribution

Submit your manuscript at www.biomedcentral.com/submit
C Biomed Central 